\title{
Use of cannabis in urological cancer patients: A review to evaluate risk for cancer development, therapeutic use, and symptom management
}

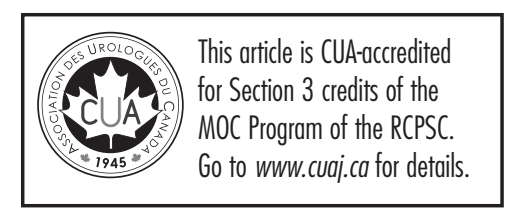

\section{Shipra Taneja, BSc[c] 1,2,3; Jen Hoogenes, PhD, MSc, MS ${ }^{1,2,3}$; Marissa Slaven, MD ${ }^{4,5}$; Anil Kapoor, MD 1,2,3,4}

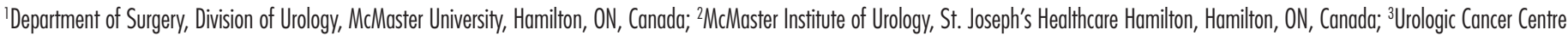
for Research \& Innovation, St. Joseph's Healthcare, Hamilton, ON Canada; ${ }^{4}$ Juravinski Cancer Centre, Juravinski Hospital, Hamilton, ON, Canada; ${ }^{5}$ Department of Family Medicine, McMaster University, Hamilton, ON, Canada

Cite as: Taneja S, Hoogenes J, Slaven M, et al. Use of cannabis in urological cancer patients: A review to evaluate risk for cancer development, therapeutic use, and symptom management. Can Urol Assoc J 2021;15(12):413-9. http://dx.doi.org/10.5489/cuaj.7198

Published online June 22, 2021

Appendix available at cuaj.ca

\section{Abstract}

Introduction: Recent recreational legalization of cannabis has resulted in an increased interest in the therapeutic effects of cannabis use in cancer patients, with reports of its use in symptom management and as a risk factor for cancer development. The objective of this review was to evaluate the literature on the association of cannabis use with the risk of cancer development, symptom management, and therapeutic management in the urological cancer (UC) patient population.

Methods: A systematic search of databases and trial registries for papers published from January 1947 to March 2020 on cannabis, symptom and therapeutic management, and cancer development in UC patients was conducted. After screening of full-text articles, data were extracted for evaluation. Studies were eligible if they were in the clinical setting, included $\geq 5 \cup C$ patients, reported use of any cannabis variant, and were written in English.

Results: The search retrieved 2456 abstracts, of which 48 full-text articles were reviewed and 21 included in the review. Low-level evidence suggested a correlation between cannabis use and risk for development of testicular cancer. Some support existed for using cannabis for cancer pain and chemotherapy-induced nausea. There was inadequate evidence to substantiate cannabis use as a therapeutic agent for management of UCs. A lack of high-level evidence and robust methodology of the studies limited evaluation of the findings. Conclusions: Given the paucity of data on cannabis use for therapeutic purposes in UC, large, prospective trials with adequate followup times to observe the effect of cannabis use on UCs are warranted to improve the evidence base.

\section{Introduction}

The recent recreational legalization of and subsequent increase in access to cannabis in Canada and some regions of the U.S. has resulted in a growing interest in the therapeutic effects of cannabis use in cancer patients. ${ }^{1}$ Delta-9tetrahydrocannabinol (THC) and cannabidiol (CBD) have been shown to possess analgesic, anti-inflammatory, and other properties ${ }^{2-4}$ that may aid in symptom treatment for cancer patients; however, the effect of cannabis on cancer development and as a therapeutic agent is largely unknown.

Misleading claims, often arising from internet articles, have suggested that cannabis may cure cancer despite a lack of clinical evidence. ${ }^{5,6}$ A study published in 2019 showed that, based on Google Trends' relative search volume tool, from 2011-2018, the online search volume for cannabis and cancer increased 10 times the rate of standard cancer therapies, with the use of cannabis as a cancer cure representing the largest category (23.5\%) of social media content on alternative treatments for cancer. ${ }^{5}$ The authors also reported that the search rate was highest in areas where medical or recreational cannabis is legal and that false news stories that claim cannabis can cure cancer received significantly more social media engagement than accurate news stories debunking this claim, finding also that legitimate cancer organizations infrequently addressed cannabis via online media. ${ }^{5}$ This assumption has led some patients to believe that cannabis possesses properties that cure malignancy, which can steer patients to selfprescribe without medical oversight. ${ }^{7}$

A recent survey of prostate cancer (PCa) patients reported that $31 \%$ of their sample believed cannabis can treat their cancer, ${ }^{8}$ while a 2017 systematic review showed no conclusive evidence to support starting cannabinoid therapy for anticancer benefit when other therapies for urological cancers (UCs) have failed. ${ }^{9}$ While evidence is lacking with respect to cannabis as a cancer treatment, there have been increasing reports of its use in other clinical capacities, such 
Taneja et al

as symptom management and its potential as a risk factor for cancer development. ${ }^{10}$ As our group previously reviewed the potential role of antiproliferative effects of cannabinoids on urological tumor activity, ${ }^{9}$ our current aim was to evaluate the available evidence on the association of cannabis use and the risk for development of $U C$, its therapeutic use, and management of symptoms in $\mathrm{UC}$ patients in the clinical setting.

\section{Methods}

\section{Search strategy}

We performed a systematic literature search using PubMed, Embase, Cochrane CENTRAL Trials Registry, and Google Scholar databases for studies published between January 1947 and March 1, 2020. References from review articles and those in our initial search were manually searched for additional sources, as well as abstracts, conference proceedings, and the grey literature. Attempts were made to contact authors of abstracts for which we could not locate full-text articles. The complete search strategy and keywords used are in the online Appendix (available at cuaj.ca). Institutional research ethics board approval was not required for this review.

\section{Selection of studies}

Two authors $(\mathrm{ST}, \mathrm{JH})$ independently screened titles and abstracts for inclusion in the full-text review. Studies were included if they met the following criteria: 1 ) included $\geq 5$ UC patients and associated use of any variant of cannabis; and 2) written in or translated to English. We excluded in vitro studies, animal studies, review articles, expert opinion pieces, articles not available in full-text, and studies that did not evaluate the use of cannabis in UC patients. There were no exclusions based on study design. The same two authors independently reviewed all full-text articles using inclusion and exclusion criteria. Disagreements were resolved by consensus and a third investigator (AK) when necessary.

\section{Data extraction and outcomes}

After full-text screening, two authors (ST, JH) reviewed all articles to extract relevant data, which included cancer type, study design, participants and setting, intervention(s), outcome measures, results, and symptoms. Outcomes included evidence relative to the association of cannabis with the risk for development of UC and its use for therapeutic and symptom management in UC patients. The results are presented as a narrative synthesis of the available literature.

\section{Results}

\section{Literature search}

The initial search across databases retrieved 3323 abstracts with 877 duplicates, leaving 2456 for screening. After title and abstract screening, 2408 were removed based on inclusion and exclusion criteria and 48 full-text articles were assessed for eligibility. Twenty-seven articles were removed after full-text review, as they did not include at least 5 UC patients and/or were not primary sources. An examination of reference lists of included studies identified 10 articles that were excluded after full-text review. A total of 21 articles were included in this review (Fig. 1). Extensive results are summarized in Tables 1 and 2, as well as Supplementary Table 1 (available at cuaj.ca).

\section{Cannabis and risk for development of UC}

\section{Bladder cancer}

The search yielded two studies that evaluated the effects of cannabis use on the risk for developing bladder cancer. Chacko et al conducted a prospective, case-control study comparing 52 transitional cell carcinoma (TCC) patients with 104 age-matched cancer-free controls (patients $<60$ years old) to elicit participants' inhaled cannabis use. ${ }^{11}$ Using the continuous variable "joint-years," $88.5 \%$ of the TCC patients and $69.2 \%$ of the controls reported habitual cannabis use (mean joint-years was 48.0 for TCC patients and 28.5 for controls, $\mathrm{p}=0.008$ ). After adjusting for other TCC risk variables, increasing joint-years remained significantly associated with TCC $(p=0.01) .{ }^{11}$ These findings were limited by a

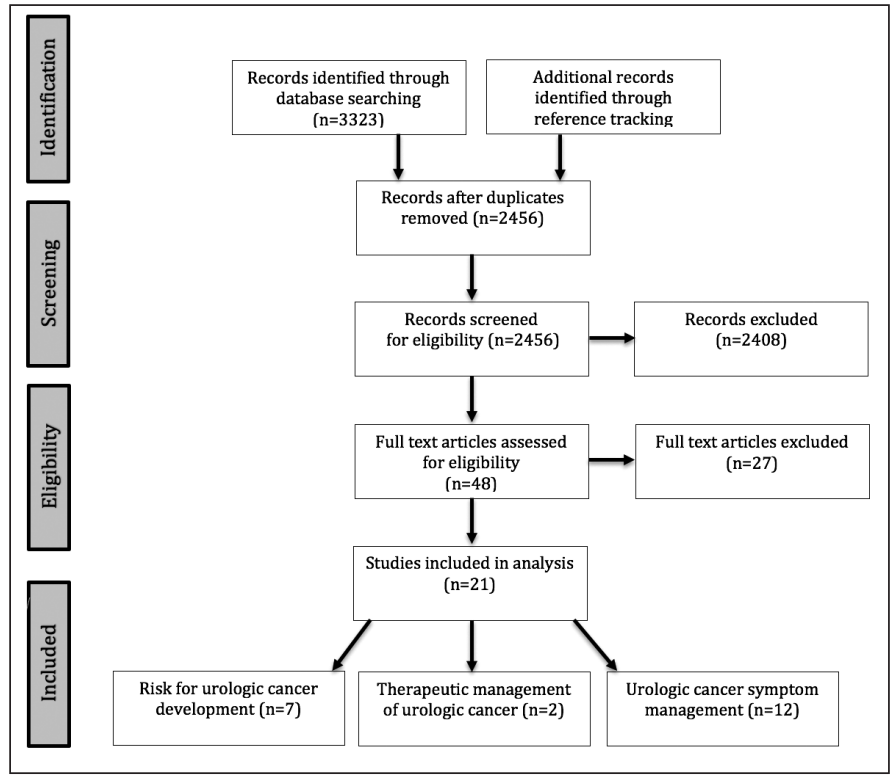

Fig. 1. Study flow diagram. 


\begin{tabular}{|c|c|c|c|c|c|}
\hline Author & $\begin{array}{l}\text { Cancer } \\
\text { type(s) }\end{array}$ & Methods & Participants and setting & $\begin{array}{l}\text { Intervention(s) and } \\
\text { outcome measures }\end{array}$ & Results \\
\hline $\begin{array}{l}\text { Chacko et } \\
\text { al }^{11}\end{array}$ & Bladder & $\begin{array}{l}\text { - Case- } \\
\text { control } \\
\text { study } \\
-\mathrm{n}=52 \\
\text { bladder } \\
\text { cancer } \\
\text { cases } \\
\text { - } \mathrm{n}=104 \\
\text { controls }\end{array}$ & $\begin{array}{l}\text { - } 52 \text { TCC patients and } \\
104 \text { age matched } \\
\text { cancer-free controls } \\
\text { - Males }<60 \text { years of age } \\
\text { from two Veterans } \\
\text { Affairs clinics in the } \\
\text { U.S. }\end{array}$ & $\begin{array}{l}\text { - Assessed } \\
\text { previous } \\
\text { exposure } \\
\text { to potential } \\
\text { carcinogens } \\
\text { (radiation, Agent } \\
\text { Orange, dyes, } \\
\text { intake of smoked } \\
\text { or processed } \\
\text { meats, tobacco, } \\
\text { and marijuana) } \\
\text { through self- } \\
\text { administered } \\
\text { questionnaire }\end{array}$ & $\begin{array}{l}-88.5 \%(n=46) \text { of cases and } 69.2 \%(n=72) \text { of } \\
\text { controls reported a history of habitual cannabis } \\
\text { use (using the continuous variable joint-years) } \\
\text { ( } p=0.008) \\
\text { - Increased joint-years was significantly associated } \\
\text { with the incidence of bladder cancer }(p=0.01) \\
\text { - Both cases and controls reported high rates of } \\
\text { tobacco usage }\end{array}$ \\
\hline $\begin{array}{l}\text { Daling et } \\
\text { al }^{16}\end{array}$ & TGCT & $\begin{array}{l}\text { - Case- } \\
\text { control } \\
\text { study } \\
\text { - } \mathrm{n}=369 \text { TGCT } \\
\text { cases } \\
\text { - } \mathrm{n}=979 \\
\text { controls }\end{array}$ & $\begin{array}{l}\text { - Cases were men aged } \\
\text { 18-44 years diagnosed } \\
\text { with invasive TGCT } \\
\text { from 1999-2006 } \\
\text { - Controls were cancer- } \\
\text { free men aged } 18-44 \\
\text { years } \\
\text { - Washington, U.S. }\end{array}$ & $\begin{array}{l}\text { - In-person } \\
\text { interviews with } \\
\text { a structured } \\
\text { questionnaire to } \\
\text { assess cigarette } \\
\text { smoking, alcohol } \\
\text { consumption, } \\
\text { recreational } \\
\text { drug use, and } \\
\text { other known or } \\
\text { suspected risk } \\
\text { factors for TGC }\end{array}$ & $\begin{array}{l}\text { - Cases }(72.6 \%) \text { were more likely to have ever } \\
\text { smoked cannabis than controls }(68 \%) \text { (OR } 1.3 \text {, } \\
95 \% \mathrm{Cl} 1.0-1.8) \\
\text { - Current cannabis use was identified more } \\
\text { frequently in non-seminoma vs. pure seminoma } \\
\text { TCGT cases ( } 38.1 \% \text { vs. } 19 \%, \mathrm{p}=0.08) \\
\text { - The risk for non-seminoma was higher in } \\
\text { patients who smoked } \\
\text { - cannabis before } 18 \text { years of age (OR } 2.8,95 \% \mathrm{Cl} \\
\text { 1.6-5.1) compared to men who started smoking } \\
\text { cannabis later in life (OR } 1.3,95 \% \mathrm{Cl} 0.6-3.2 \\
\text { (p=0.08) } \\
\text { - A } 70 \% \text { increased risk of TGCT was associated } \\
\text { with current cannabis use (OR } 2.3,95 \% \mathrm{Cl} \\
1.3-4.0 \text { ); this was elevated when used daily or } \\
\text { weekly vs. less than once per week (ORs } 3.0 \text { vs. } \\
1.8 \text { ) }\end{array}$ \\
\hline $\begin{array}{l}\text { Lacson et } \\
\text { al }^{14}\end{array}$ & TGCT & $\begin{array}{l}\text { - Case- } \\
\text { control } \\
\text { study } \\
\text { - } \mathrm{n}=163 \text { TGCT } \\
\text { cases } \\
\text { - } \mathrm{n}=292 \\
\text { controls }\end{array}$ & $\begin{array}{l}\text { - Men 18-35 years } \\
\text { of age, who were } \\
\text { diagnosed with TGCT } \\
\text { between December } \\
1986 \text { and April } 1991 \\
\text { - Controls were men } \\
\text { matched by race, } \\
\text { ethnicity, date of birth, } \\
\text { and neighborhood of } \\
\text { residence } \\
\text { - California, U.S. }\end{array}$ & $\begin{array}{l}\text { - Interviews } \\
\text { using structured } \\
\text { questionnaires to } \\
\text { identify personal } \\
\text { use and duration } \\
\text { of tobacco, } \\
\text { alcohol, and } \\
\text { multiple types } \\
\text { of recreational } \\
\text { drugs }\end{array}$ & $\begin{array}{l}\text { - Self-reported ever use of inhaled cannabis led to } \\
\text { a two-fold increase in risk for TGCT compared to } \\
\text { never use (OR 1.94, 95\% Cl 1.02-3.68) } \\
\text { - Former inhaled cannabis users had a greater } \\
\text { than two-fold risk of TGCT compared to never } \\
\text { users (OR 2.28, 95\% Cl 1.17-4.43) } \\
\text { - Current inhaled cannabis users had a non- } \\
\text { significant increase in TGCT risk compared to } \\
\text { never users (OR 1.38, 95\% Cl 0.67-2.87) }\end{array}$ \\
\hline $\begin{array}{l}\text { Sidney et } \\
\mathrm{al}^{13}\end{array}$ & Prostate & $\begin{array}{l}\text { - Retrospec- } \\
\text { tive cohort } \\
\text { study } \\
\text { - n=64 } 855\end{array}$ & $\begin{array}{l}\text { - Participants from } \\
\text { Kaiser Permanente } \\
\text { Medical Care Program } \\
\text { between ages 15-49 } \\
\text { - San Francisco, U.S. }\end{array}$ & $\begin{array}{l}\text { - Participants } \\
\text { completed self- } \\
\text { administered } \\
\text { research } \\
\text { questionnaires } \\
\text { from 1979-1985 } \\
\text { about tobacco, } \\
\text { marijuana, and } \\
\text { alcohol }\end{array}$ & $\begin{array}{l}\text { - Current and ever use of inhaled cannabis by } \\
\text { non-smokers of tobacco were associated with an } \\
\text { increased risk of developing prostate cancer (RR } \\
4.7,95 \% \mathrm{Cl} 1.4-15.5 \text { and RR } 3.1,95 \% \mathrm{Cl} 1.0-9.5) \\
\text { - There was a two-fold increase in the risk of } \\
\text { prostate cancer for participants who used } \\
\text { cannabis one or more times per week compared } \\
\text { to non-users }\end{array}$ \\
\hline
\end{tabular}

large number of tobacco users (possible synergetic carcinogenic effect) and selection and recall bias.

Thomas et al evaluated 82050 men in the California Men's Health Study to determine whether inhaled cannabis was associated with bladder cancer development. ${ }^{12}$ Baseline surveys completed in 2002-2003 were compared with the incidence of bladder cancer over the following 11 years, as indicated in electronic medical records. Results showed that $0.3 \%$ of cannabis users developed bladder cancer compared to $0.4 \%$ of non-users $(p<0.001)$. After adjusting for 
Taneja et al

\begin{tabular}{|c|c|c|c|c|c|}
\hline Author & $\begin{array}{l}\text { Cancer } \\
\text { type(s) }\end{array}$ & Methods & Participants and setting & $\begin{array}{l}\text { Intervention(s) and } \\
\text { outcome measures }\end{array}$ & Results \\
\hline $\begin{array}{l}\text { Thomas } \\
\text { et } \mathrm{al}^{12}\end{array}$ & Bladder & $\begin{array}{l}\text { - Prospec- } \\
\text { tive cohort } \\
\text { study with } \\
82050 \text { men } \\
\text { - } \mathrm{n}=34000 \\
\text { cannabis } \\
\text { users }\end{array}$ & $\begin{array}{l}\text { - Men ages } 45-69 \text { years } \\
\text { in the California Men's } \\
\text { Health Study Database } \\
\text { - California, U.S. }\end{array}$ & $\begin{array}{l}\text { - Questionnaires } \\
\text { assessed the } \\
\text { number of times } \\
\text { cannabis was } \\
\text { used over an } \\
11 \text {-year period }\end{array}$ & $\begin{array}{l}\text { - } 34000 \text { men reported using cannabis, with } 17 \% \\
\text { using it over } 500 \text { times } \\
\text { - } 89(0.3 \% \text { ) of cannabis users developed bladder } \\
\text { cancer compared to } 190 \text { ( } 0.4 \% \text { ) non-cannabis } \\
\text { users ( } \mathrm{p}<0.001 \text { ) } \\
\text { - Cannabis use was associated with a } 45 \% \\
\text { reduction in bladder cancer risk after adjusting } \\
\text { for multiple variables (HR } 0.55,95 \% \mathrm{Cl} 0.31-1.00 \text { ) } \\
\text { - Men using cannabis over } 500 \text { times were } 31 \% \\
\text { less likely to develop bladder cancer (adjusted } \\
\text { HR } 0.69,95 \% \mathrm{Cl} 0.38-1.27 \text { ) } \\
\text { - Older men using both cannabis and tobacco } \\
\text { had non-statistically significant increased risk for } \\
\text { developing bladder cancer (adjusted HR } 1.28, \\
95 \% \mathrm{Cl} 0.88-1.86 \text { ) }\end{array}$ \\
\hline $\begin{array}{l}\text { Trabert et } \\
\mathrm{al}^{15}\end{array}$ & TGCT & $\begin{array}{l}\text { - Case- } \\
\text { control } \\
\text { study } \\
\text { - } \mathrm{n}=187 \text { TGCT } \\
\text { cases } \\
\text { - } \mathrm{n}=148 \\
\text { controls }\end{array}$ & $\begin{array}{l}\text { - Case- control study } \\
\text { - } n=187 \text { TGCT cases } \\
\text { - } n=148 \text { controls }\end{array}$ & $\begin{array}{l}\text { - Assessed lifestyle } \\
\text { habits, drug } \\
\text { use (duration), } \\
\text { medical history, } \\
\text { and diet using } \\
\text { self-administered } \\
\text { surveys }\end{array}$ & $\begin{array}{l}\text { - Cases were twice as likely to be frequent } \\
\text { cannabis users than controls ( } 18.2 \% \text { vs } 7.1 \% \text {, OR } \\
2.2,95 \% \mathrm{Cl} 1.0-5.1) \\
\text { - Non-seminoma TGCT was associated with more } \\
\text { frequent cannabis use than pure seminoma } \\
\text { TGCT ( } 22.3 \% \text { vs. } 14.3 \% \text {, OR } 3.1,95 \% \mathrm{Cl} 1.2-1.8) \\
\text { and long-term cannabis use of } 10 \text { or more years } \\
\text { (21.5\% vs. } 10.2 \% \text {, OR } 2.4,95 \% \mathrm{Cl} 1.0-6.1)\end{array}$ \\
\hline $\begin{array}{l}\text { Callaghan } \\
\text { et } \mathrm{al}^{17}\end{array}$ & TGCT & $\begin{array}{l}\text { - Retrospec- } \\
\text { tive cohort } \\
\text { study, } \\
\text { n=49 } 343 \\
\text { - } \mathrm{n}=119 \text { TGCT } \\
\text { cases }\end{array}$ & $\begin{array}{l}\text { - Participants were from } \\
\text { a cohort of Swedish } \\
\text { military service } \\
\text { - Cases had been } \\
\text { diagnosed with } \\
\text { testicular cancer } \\
\text { between } 1970 \text { and } 2011\end{array}$ & $\begin{array}{l}\text { - Self-reported use } \\
\text { of alcohol, drugs, } \\
\text { and tobacco at } \\
\text { time of military } \\
\text { enlistment }\end{array}$ & $\begin{array}{l}\text { - Heavy cannabis use (>50 times) was associated } \\
\text { with a higher incidence of testicular cancer } \\
\text { (adjusted HR } 2.57,95 \% \mathrm{Cl} 1.02-6.50 \text { ) } \\
\text { - No significant association between ever use of } \\
\text { cannabis and subsequent diagnosis of testicular } \\
\text { cancer (adjusted HR } 1.42,95 \% \mathrm{Cl} 0.83-2.45 \text { ) }\end{array}$ \\
\hline
\end{tabular}

Cl: confidence interval; HR: hazard ratio; OR: odds ratio; RR: relative risk; TCC: transitional cell carcinoma TGCT: testicular germ cell tumor.

multiple variables, cannabis use alone was shown to be associated with a $45 \%$ reduction in bladder cancer risk (hazard ratio $[\mathrm{HR}] 0.55,95 \%$ confidence interval $[\mathrm{Cl}] 0.31-1.00) .^{12}$ Limitations included participation and response biases, lack of evaluation of other bladder cancer risk factors, lack of assessment of the time course between cannabis use and diagnosis, and no reported average cannabis use. ${ }^{10}$

\section{Prostate cancer}

One study on cannabis use and the risk for developing PCa was found. Sidney et al reported current and ever use of inhaled cannabis by non-smokers of tobacco were associated with an increased risk of developing PCa (relative risk [RR] 4.7, 95\% Cl 1.4-15.5; and RR 3.1, 95\% Cl 1.0-9.5, respectively). Cannabis use of $\geq 1$ time per week was associated with a two-fold increase in the risk of PCa compared to non-users and experimenters, although this was not significant. ${ }^{13} \mathrm{PCa}$ cases were relatively young compared to the general population (maximum age of 63). ${ }^{13} \mathrm{~A}$ systematic review evaluated this study, reporting a moderate level of bias, as well as insufficient evidence that is limited by a lack of adjustment of key confounders and quantification of cannabis exposure. ${ }^{10}$

\section{Testicular cancer}

Four studies examined the association between cannabis use and the development of testicular cancer. ${ }^{14-17}$ Pooled data of three case control studies showed a significant association between development of testicular germ cell tumour (TGCT) and current (at the reference point), frequent, and lengthy cannabis use. ${ }^{18}$ Two meta-analyses of these studies ${ }^{18,19}$ observed that current cannabis use increased TGCT risk by $62 \%$ (odds ratio [OR] 1.62, 95\% Cl 1.13-2.31), frequent use almost doubled the risk of developing TGCT (OR 1.92, 95\% $\mathrm{Cl} 1.35-2.72$ ), and there was an association between duration of use ( $\geq 10$ years vs. never use) and TGCT development (OR 1.50, 95\% Cl 1.08-2.09). When compared to pure TGCT seminoma, current and frequent cannabis use doubled the odds of non-seminoma development (OR 2.09, 95\% Cl 129-3.37; and OR 2.59, 95\% Cl 1.60-4.19, respectively). No association with ever use of inhaled cannabis and TGCT risk was found. ${ }^{18,19}$ There was a high level of agreement between studies, with $\mathrm{I}^{2}$ values of $0 \%$ for most exposure variables. ${ }^{18}$

The fourth study, by Callaghan et al, retrospectively observed 119 men diagnosed with testicular cancer between 1970 and 2011, finding that heavy inhaled cannabis use 


\begin{tabular}{|c|c|c|c|c|c|c|}
\hline Author & $\begin{array}{l}\text { Cancer } \\
\text { type(s) }\end{array}$ & Methods & Participants and setting & Intervention(s) & Outcomes & Results \\
\hline $\begin{array}{l}\text { Kenyon } \\
\text { et } \mathrm{al}^{7}\end{array}$ & $\begin{array}{l}\text { Bladder, } \\
\text { prostate }\end{array}$ & $\begin{array}{l}\text { - Case report } \\
-\mathrm{N}=119 \text { total } \\
-\mathrm{n}=18 \text { UC } \\
\text { patients }\end{array}$ & $\begin{array}{l}-28 \text { of the } 119 \text { patients } \\
\text { were given CBD as } \\
\text { an only treatment; of } \\
\text { those, } 6 \text { were prostate } \\
\text { cancer patients; } \\
\text { bladder cancer patients } \\
\text { were included but not } \\
\text { described } \\
\text {-London, U.K. }\end{array}$ & $\begin{array}{l}\text {-1 mg of CBD } \\
\text { in neutral oil } \\
\text {-Average } \\
\text { dose 10mg } \\
\text { twice a day; } \\
\text { administered } \\
\text { 3-days-on, } \\
\text { 3-days-off } \\
\text { for minimum } \\
\text { of } 6 \text { months }\end{array}$ & $\begin{array}{l}\text {-Circulating } \\
\text { tumor cell } \\
\text { test before } \\
\text { and after } \\
\text { treatment }\end{array}$ & $\begin{array}{l}\text { - The results of one prostate cancer } \\
\text { patient were reported, which showed } \\
\text { a reduction in circulating tumour } \\
\text { cells with CBD alone from an initial } \\
8.1 \text { cells } / 7.5 \mathrm{~mL} \text { to } 5.9 \text { cells } / 7.5 \mathrm{~mL} \text {, } \\
\text { with a steady reduction over the } \\
\text { course of } 12 \text { months of } 4.8,4.2 \text {, and } \\
3.2 / 7.5 \mathrm{~mL} \\
\text { - No data were provided for the other } 5 \\
\text { prostate cancer patients in the study }\end{array}$ \\
\hline $\begin{array}{l}\text { Taha et } \\
\mathrm{al}^{20}\end{array}$ & $\mathrm{RCC}$ & $\begin{array}{l}\text { - Retrospective } \\
\text { chart review } \\
-\mathrm{N}=140 \text { total } \\
-\mathrm{n}=42 \mathrm{RCC} \\
\text { patients, } \\
\text { including } \\
\text { melanomas } \\
\text { (grouped } \\
\text { together) }\end{array}$ & $\begin{array}{l}\text {-Two arms: nivolumab } \\
\text { alone }(n=89) \text { and } \\
\text { nivolumab plus } \\
\text { cannabis ( } n=51 \text { ) } \\
\text { - Israel }\end{array}$ & $\begin{array}{l}-20-30 \mathrm{~g} \text { or } \\
\text { more of } \\
\text { cannabis } \\
\text { per month, } \\
\text { with cutoffs } \\
\text { of } 10 \% \text { THC } \\
\text { and } 1 \% \text { CBD }\end{array}$ & $\begin{array}{l}\text { - Clinical } \\
\text { influence of } \\
\text { cannabis use } \\
\text { measured by } \\
\text { RR, PFS, and } \\
\text { OS }\end{array}$ & $\begin{array}{l}\text { - Cannabis was not a significant for } \\
\text { PFS, but was a weak significant factor } \\
\text { for OS (HR 1.58, 95\% Cl, 1.01-2.46, } \\
\text { p=0.045) } \\
\text { - In the RCC and melanoma group, the } \\
\text { RR was } 10 \% \text { for those with cannabis + } \\
\text { nivolumab and } 43.3 \% \text { for nivolumab } \\
\text { alone (OR } 0.15,95 \% \mathrm{Cl} 0.02-1.3 \text {, } \\
\text { p=0.084) }\end{array}$ \\
\hline
\end{tabular}

(>50 times) was associated with testicular cancer (adjusted HR 2.57, 95\% Cl 1.02-6.50). ${ }^{17}$ This study was limited, as the data collection point was from 1969-1970 via self-report, with no followup data other than testicular cancer diagnosis, potentially causing spurious findings and misclassification bias. Histological data were not reported.

\section{Cannabis and therapeutic management of UC}

\section{Renal cancer}

One retrospective chart review study ${ }^{20}$ evaluated the clinical influence of cannabis use on clear-cell renal cell carcinoma (cCRCC) and other cancers during immunotherapy with nivolumab. Findings showed that cannabis was not a significant predictor for progression-free survival but was a weak significant factor for overall survival (HR 1.58, 95\% Cl 1.01-2.46, $\mathrm{p}=0.045) .^{20}$ The study was limited in that it was retrospective with a short followup period and used a non-representative ccRCC patient population given the cohort size differences.

\section{Prostate cancer}

The therapeutic use of cannabis in PCa was identified in a prospective evaluation of the use of synthetic pharmaceuticalgrade CBD oil in 119 advanced cancer patients. ${ }^{7}$ Six PCa patients received the oil in prescribed doses and a circulating tumor cell (CTC) test was conducted at baseline and after treatment. Results were provided in case report format only, where one PCa patient had reduced CTCs from an initial 8.1 cells $/ 7.5 \mathrm{ml}$, with steady reduction over 12 months of 4.8 , 4.2 , and 3.2 cells $/ 7.5 \mathrm{ml}$ shown. Results for the remaining five PCa patients were not reported. These data provide anecdotal information and do not account for potential confounders.

\section{Cannabis and UC symptom management}

\section{Cancer pain}

Six studies (five randomized controlled trials [RCTs] and one chart review) on cannabis use and UC pain were evaluated (included prostate, bladder, kidney, and unspecified urogenital cancers). Across these studies, pain worsened in advanced cancer patients who were not using cannabis, ${ }^{21}$ while either reducing ${ }^{22-24}$ or remaining unchanged ${ }^{21,25}$ in those using any form of cannabis (THC:CBD or THC alone). The majority of cannabis users reduced their opioid doses, while most patients in placebo groups increased their dosages..$^{21,22}$ In assessing the safety of THC:CBD $(27 \mathrm{mg} / \mathrm{ml}: 25 \mathrm{mg} / \mathrm{ml})$, one study found low (1-4 sprays) and medium (6-10 sprays) doses were welltolerated and improved pain compared to high dosages (11-16 sprays) that caused multiple side effects. ${ }^{26}$ The long-term use of cannabis was found to be well-tolerated in patients, with continuation of pain improvement. ${ }^{24}$ While the RCTs suggested that the use of oromucosal Sativex ${ }^{\circledR}$ may be a safe and effective adjunct to opioid treatment, ${ }^{22-26}$ they were limited, as they relied on self-report with no objective evaluation component and used patient-administered dosing, which can cause protocol deviation. Results based on individual cancer sites were not always provided. Two systematic reviews and meta-analyses evaluated these RCTs, concluding that the evidence was poor while finding minimal changes in overall cancer pain. ${ }^{27,28}$

\section{Chemotherapy-induced nausea (CIN) and anorexia}

Our search returned six studies on cannabis use for CIN and two for anorexia, each of which studied multiple types of cancer, including UCs. In the CIN studies, nausea was rated as less 
severe and/or frequent with the use of cannabis (nabilone or levonantradol) prior to and/or after chemotherapy compared to placebo ${ }^{29}$ or alternative treatment (prochlorperazine, metoclopramide, alizapride). ${ }^{30-32}$ Patients also reported significantly fewer vomiting episodes when using cannabis during chemotherapy. ${ }^{29-32}$ The majority of patients indicated that cannabis was their preferred choice of antiemetic treatment for future rounds of chemotherapy, despite side effect risk. ${ }^{29-32}$

In the two RCTs on anorexia, patients reported increased appetite with cannabis (THC:CBD and THC alone) vs. placebo. ${ }^{33,34}$ Brisbois et al demonstrated that THC improved taste, smell perception, and appetite in cannabis-treated patients, ${ }^{34}$ while Strasser et al showed that THC patients reported an increase in appetite while the placebo group reported decreased appetite or no change. ${ }^{33}$ Results for both studies were provided in aggregate without specification of $\cup C$ patients and relied on patient dosing and self-report, introducing potential for bias. Previously reported studies in our review observed appetite as a secondary endpoint, with reports that levonantrado ${ }^{30}$ and nabilone ${ }^{31}$ improved appetite, while others found that THC:CBD and $\mathrm{THC}^{22}$ and nabilone ${ }^{32}$ led to a slight reduction in appetite.

\section{Discussion}

As interest in the use of cannabis for its potential therapeutic benefits increases, an understanding of the available evidence is necessary to support informed clinical decision-making for patients with UCs. Our review demonstrated an inconsistency in the literature evaluating the use of cannabis and its association with the risk for development of bladder and prostate cancer, while some low-level evidence supports an association between cannabis use and an elevated risk for development of TGCT. ${ }^{10,14-17}$ With respect to the data reported on TGCT, the findings from each study and the meta-analyses do not imply a causal relationship, although they suggest a positive relationship. Few data exist on the therapeutic effect(s) of cannabis in renal and prostate cancer patients, with no robust findings when used with immunotherapy or evaluation of CTCs. Our review found some evidence to suggest cannabis use can alleviate UC-related pain and CIN, but contradictory findings existed for appetite improvement.

The recent recreational legalization of and ease of accessibility to cannabis presents new challenges for clinicians, as patients may incorrectly believe that cannabis can "cure" their cancers and may be more willing to discuss cannabis as a treatment. ${ }^{35}$ The limited data on antiproliferative agents ${ }^{9}$ and therapeutic properties of cannabis in $U C$ precludes the provision of evidence-based recommendations to patients. Results of a 2016 survey showed that only $30 \%$ of medical oncologists felt knowledgeable enough to make recommendations to patients about cannabis use. ${ }^{35}$ Several consensus statements are available to guide practitioners on the use of cannabis with certain cancer patient populations, largely indicating there is inconclusive evidence for the use of cannabis for treatment of cancer and related symptoms, and that additional research is required. ${ }^{36-38}$

Our findings demonstrate the need for large, randomized trials to evaluate cannabis use in $U C$ patients, with adequate followup time to evaluate cancer progression to improve the evidence base. Several clinical trials currently registered at clinicaltrials.gov are exploring the use of cannabis for UC-related symptom management. One is evaluating palliative patients with solid tumors taking cannabis for cancer treatment-related symptom management (NCT03617692), ${ }^{39}$ another is assessing the use of cannabis oil for patients with poorly controlled cancer pain (NCT03522467) ${ }^{40}$ and a RCT is evaluating the safety and efficacy of inhaled cannabis for uncontrolled pain in patients with advanced cancer (NCT04042545). ${ }^{41}$ In addition to symptom management, further study is required to determine whether there is an association between cannabis use and UC development, as well as its therapeutic use with UC patients in a clinical setting, especially with respect to progression-free and overall survival measures.

This review is not without limitations. We included clinical-based studies that contained at least five UC patients and as such, we may have overlooked relevant studies that did not specifically state the number of UC patients. Most studies included multiple cancer types in their sample populations, with some only reporting results in aggregate, which at times did not allow us to parse out the specific findings for each type of cancer. In turn, this may have limited the generalizability of some results, while also making it difficult to discern the strength of the evidence of specific UC-related results. Many studies were limited by potential confounders (e.g., tobacco smoking), methodological flaws, and risk for biases. Furthermore, we were unable to conduct any metaanalyses due to the aggregate reporting, and there was no uniform reporting of UC-related results.

\section{Conclusions}

In this review, low-level evidence suggested a correlation between cannabis use and risk for development of testicular cancer; some support existed for using cannabis for cancer pain and $\mathrm{CIN}$; and there was inadequate data to substantiate cannabis use as a therapeutic agent for UC. A lack of high-level evidence and robust methodology limited the evaluation of cannabis use in UC patients in the clinical setting. Large, high-quality, prospective trials with adequate followup time to observe the effects of cannabis use on UCs are needed to improve the evidence base, which in turn, will provide data for clinicians who treat this patient population.

Competing interests: The authors do not report any competing personal or financial interests related to this work. 
This paper has been peer-reviewed.

\section{References}

1. Pergam SA, Woodfield MC, Lee CM, et al. Cannabis use among patients at a comprehensive cancer center in a state with legalized medicinal and recreational use. Cancer 2017;123:4488-97. https://doi.org/10.1002/cncr.30879

2. Urits I, Borchart $M$, Hasegawa $M$, et al. An update of current cannabis-based pharmaceuticals in pain medicine. Pain Ther 2019;8:41-51. htrps://doi.org/10.1007/s40122-019-0114-4

3. Zaki P, Blake A, Wolt A, et al. The use of medical cannabis in cancer patients. J Pain Manage 2017;10:35362. https://www.researchgate.net/publication/324088950_The_use_of_medical_cannabis_in_cancer_patients

4. Dariš B, Verboten MT, Knez Ž, et al. Cannabinoids in cancer treatment: Therapeutic potential and legislation. Bosn J Basic Med Sci 2019;19:14-23. https://doi.org/10.17305/bibms.2018.3532

5. Shi S, Brant AR, Sabolch A, et al. False news of a cannabis cancer cure. Cureus 2019;11:e3918. https://doi.org/10.7759/cureus.3918

6. Maida V, Daeninck PJ. A user's guide to cannabinoid therapies in oncology. Curr Oncol 2016;23:398-06. https://doi.org/10.3747/co.23.3487

7. Kenyon J, Liu W, Dalgleish A. Report of objective clinical responses of cancer patients to pharmaceuticalgrade synthetic cannabidiol. Anticancer Res 2018;38:5831-5. https://doi.org/10.21873/anticanres. 12924

8. Mousa A, Petrovic M, Fleshner NE. Prevalence and predictors of cannabis use among men receiving androgen-deprivation therapy for advanced prostate cancer. Can Urol Assoc J 2020;14:E20-6. https://doi.org/10.5489/cuai.5911

9. Gandhi S, Vasisth G, Kapoor A. Systematic review of the potential role of cannabinoids as antiproliferative agents for urological cancers. Can Urol Assoc J2017; 11:E138-42. https://doi.org/10.5489/cuaj.4371

10. Ghasemiesfe $M$, Barrow B, Leonard $S$, et al. Association between marijuana use and risk of cancer: A systematic review and meta-analysis. JAMA Netw Open 2019;2:e1916318. https://doi.org/10.1001/ jamanetworkopen.2019.16318

11. Chacko JA, Heiner JG, Siu W, et al. Association between marijuana use and transitional cell carcinoma. Urology 2006;67:100-4. https://doi.org/10.1016/j.urology.2005.07.005

12. Thomas AA, Wallner $L P$, Quinn VP, et al. Association between cannabis use and the risk of bladder cancer: Results from the California men's health study. Urology 2015;85:388-92. https://doi.org/10.1016/i urology.2014.08.060

13. Sidney S, Quesenberry CP, Friedman GD, et al. Marijuana use and cancer incidence (California, United States). Cancer Causes Control 1997;8:722-8. https://doi.org/10.1023/A:1018427320658

14. Lacson JCA, Carroll JD, Tuazon E, et al. Population-based case-control study of recreational drug use and testis cancer risk confirms an association between marijuana use and non-seminoma risk. Cancer 2012;118:5374-83. https://doi.org/10.1002/cncr.27554

15. Trabert B, Sigurdson AJ, Sweeney AM, et al. Marijuana use and testicular germ cell tumors. Cancer 2011;117:848-53. https://doi.org/10.1002/cncr.25499

16. Daling JR, Doody DR, Sun X, et al. Association of marijuana use and the incidence of testicular germ cell tumors. Cancer 2009;115:1215-23. https://doi.org/10.1002/cncr.24159

17. Callaghan RC, Allebeck P, Akre 0 , et al. Cannabis use and incidence of testicular cancer: A 42-year followup of Swedish men between 1970 and 2011. Cancer Epidemiol Biomark Prev 2017;26:1644-52. https://doi.org/10.1158/1055-9965.EP-17-0428

18. Gurney J, Shaw C, Stanley J, et al. Cannabis exposure and risk of testicular cancer: A systematic review and meta-analysis. BMC Cancer 2015; 15:897. https://doi.org/10.1186/s12885-015-1905-6

19. Huang YH, Zhang ZF, Tashkin DP, et al. An epidemiologic review of marijuana and cancer: an update. Cancer Epidemiol Biomark Prev 2015;24:15-31. hitps://doi.org/10.1158/1055-9965.EPI-14-1026

20. Taha $T$, Meiri D, Talhamy $S$, et al. Cannabis impacts tumor response rate to nivolumab in patients with advanced malignancies. Oncologist 2019;24:549-54. https://doi.org/10.1634/theoncologist.2018-0383

21. Pawasarat IM, Schultz EM, Frisby JC, et al. The efficacy of medical marijuana in the treatment of cancerrelated pain. J Palliat Med 2020;23:809-16. https://doi.org/10.1089/ipm.2019.0374

22. Johnson JR, Burnell-Nugent $M$, Lossignol $D$, et al. Multicenter, double-blind, randomized, placebocontrolled, parallel-group study of the efficacy, safety, and tolerability of THC:CBD extract and THC extract in patients with intractable cancer-related pain. J Pain Symptom Manage 2010;39:167-79. https://doi.org/10.1016/i.jpainsymman.2009.06.008

23. Lichtman AH, Lux EA, McQuade R, et al. Results of a double-blind, randomized, placebo-controlled study of nabiximols oromucosal spray as an adjunctive therapy in advanced cancer patients with chronic uncontrolled pain. J Pain Symptom Manage 2018;55:179-88. https://doi.org/10.1016/i.jpainsymman.2017.09.001
24. Johnson JR, Lossignol D, Burnell-Nugent $M$, et al. An open-label extension study to investigate the long-term safety and tolerability of THC/CBD oromucosal spray and oromucosal THC spray in patients with terminal cancer-related pain refractory to strong opioid analgesics. J Pain Symptom Manage 2013;46:207-18. https://doi.org/10.1016/i.jpainsymman.2012.07.014

25. Fallon MT, Albert Lux E, McQuade R, et al. Sativex oromucosal spray as adjunctive therapy in advanced cancer patients with chronic pain unalleviated by optimized opioid therapy: Two double-blind, randomized, placebo-controlled phase 3 studies. Br J Pain 2017;11:119-33. https://doi.org/10.1177/2049463717710042

26. Portenoy RK, Ganae-Motan ED, Allende S, et al. Nabiximols for opioid-treated cancer patients with poorlycontrolled chronic pain: a randomized, placebo-controlled, graded-dose trial. J Pain 2012;13:438-49. https://doi.org/10.1016/i.jpain.2012.01.003

27. Häuser W, Welsch P, Klose P, et al. Efficacy, tolerability and safety of cannabis-based medicines for cancer pain. Schmerz 2019;33:424-36. https://doi.org/10.1007/s00482-019-0373-3

28. Boland EG, Bennett MI, Allgar V, et al. Cannabinoids for adult cancer-related pain: Systematic review and meta-analysis. BMJ Support Palliat Care 2020;10:14-24. https://doi.org/10.1136/bmispcare-2019-002032

29. Wada JK, Bogdon DL, Gunnell JC, et al. Double-blind, randomized, crossover trial of nabilone vs. placebo in cancer chemotherapy. Cancer Treat Rev 1982;9:S39-44. https://doi.org/10.1016/S03057372(82)80034-0

30. Heim ME, Queisser W, Altenburg HP. Randomized crossover study of the antiemetic activity of levonantradol and metoclopramide in cancer patients receiving chemotherapy. Cancer Chemother Pharmacol 1984;13:123-5. https://doi.org/10.1007/BF00257128

31. Niederle N, Schütte J, Schmidt CG. Crossover comparison of the antiemetic efficacy of nabilone and alizapride in patients with non-seminomatous testicular cancer receiving cisplatin therapy. Klin Wochenschr 1986;64:362-5. https://doi.org/10.1007/BF01728184

32. Einhorn $L H$, Nagy C, Furnas B, et al. Nabilone: An effective antiemetic in patients receiving cancer chemotherapy. J Clin Pharmacol 1981;21:S64-9. https://doi.org/10.1002/j.1552-4604.1981.tb02576.x

33. Strasser F, Luftner D, Possinger K, et al. Comparison of orally administered cannabis extract and delta-9tetrahydrocannabinol in treating patients with cancer-related anorexia-cachexia syndrome: A multicenter, phase 3, randomized, double-blind, placebo-controlled clinical trial from the cannabis-in-cachexia-studygroup. J Clin Oncol 2006;24:3394-00. hitps://doi.org/10.1200/JC0.2005.05.1847

34. Brisbois TD, de Kock IH, Watanabe SM, et al. Delta-9-tetrahydrocannabinol may palliate altered chemosensory perception in cancer patients: Results of a randomized, double-blind, placebo-controlled pilot trial. Ann Oncol 2011;22:2086-93. htrps://doi.org/10.1093/annonc/mdq727

35. Braun IM, Wright A, Peteet J, et al. Medical oncologists' beliefs, practices, and knowledge regarding marijuana used therapeutically: a nationally representative survey study. J Clin Oncol 2018;36:1957-62. https://doi.org/10.1200/JC0.2017.76.1221

36. Allan GM, Ramii J, Perry D, et al. Simplified guideline for prescribing medical cannabinoids in primary care. Can Fam Physician. 2018;64:111-20. http://www.ncbi.nlm.nih.gov/pmc/articles/pmc5964385/

37. Evans W, Durocher-Allen LD, Daeninck P, et al. Cancer and the health effects of cannabis and cannabinoids: An update of the national academies of sciences, engineering, and medicine. Published June 29, 2020. Available at: hitps://www.cancercareontario.ca/en/guidelines-advice/types-of-cancer/66536. Accessed Nov. 5, 2020.

38. The American Cancer Society. Marijuana and cancer. Published Aug. 4, 2020. Available at: https://www. cancer.org/treatment/treatments-and-side-effects/complementary-and-alternative-medicine/marijuanaand-cancer.html. Accessed Nov. 6, 2020.

39. Bryan A. Effects of cannabis use in cancer patients: A feasibility study. Published Aug. 18, 2018. Available at: https://clinicaltrials.gov/ct2/show/NCT03617692. Accessed Nov. 5, 2020.

40. Slaven M. Cannabis oil for pain effectiveness. Published Sept. 25, 2019. Available at: https://dinicaltrials. gov/ct2/show/NCT03522467. Accessed Nov. 6, 2020.

41. Matharan S. Safety and efficacy of inhaled cannabis for the uncontrolled pain relief in patients with advanced cancer (PLENITUDE). Published March 12, 2020. Available at: https://clinicaltrials.gov/ct2/ show/NCT04042545. Accessed Dec. 4, 2020.

Correspondence: Dr. Anil Kapoor, Department of Surgery, Division of Urology, McMaster University, Hamilton, 0N, Canada; akapoor@mcmaster.ca

To answer the multiple-choice questions associated with this article, go to: www.cuasection3credits.org/cuajdecember2021. This program is an Accredited Self-Assessment Program (Section 3) as defined by the Maintenance of Certification Program of The Royal College of Physicians \& Surgeons of Canada, and approved by the Canadian Urological Association. Remember to visit MAINPORT (www.mainport.org/mainport/) to record your learning and outcomes. You may claim a maximum of 1 hour of credit. 